\title{
Cetacean ocurrence in the Santa Marta Region, Colombian CaribBean, 2004-2005
}

\author{
Mario A. Pardo ${ }^{1,2, *}$ and Daniel M. Palacios ${ }^{3,4}$
}

Keywords: cetacean occurrence, cetacean distribution, Santa Marta, Colombia, southwestern Caribbean, opportunistic observations, incidental mortality

Located on the central coast of the Colombian Caribbean, the region of Santa Marta and the adjacent Tayrona National Natural Park (TNNP) $\left(11^{\circ} 14^{\prime} \mathrm{N}, 74^{\circ} 14^{\prime} \mathrm{W}\right)$ comprise a variety of tropical coastal habitats such as rocky shores, coral patches, small mangrove lagoons, sea grass meadows, and sandy bottoms (Garzón-Ferreira and Cano, 1991; Díaz et al., 2000). The geomorphology of the region is shaped by the incursion into the sea of the foothills of a steep coastal mountainous system known as the "Sierra Nevada de Santa Marta", leading to the absence of a wide shelf in most of the region, and to the presence of great depths near the coast (Ramírez, 1983; Molina, 19905) (Figure 1). The two main sources of biological productivity are driven by the climatic regime: during the dry season (December to April), trade winds blowing from the northeast cause upwelling events and phytoplankton blooms at several locations along the coast, whereas in the rainy season (May to November), the ocean is fertilized by coastal runoff and riverine inputs (Müller, 1979; Bula-Meyer, 1985; Pujos et al., 1986; FrancoHerrera et al., 2006).

The presence of cetaceans in this region is known from isolated records for eight species: ordinary Bryde's whale (Balaenoptera brydei), humpback whale (Megaptera novaeangliae), pygmy sperm whale (Kogia breviceps), rough-toothed dolphin (Steno bredanensis), marine tucuxi (Sotalia guianensis), common bottlenose dolphin (Tursiops truncatus), Atlantic spotted dolphin (Stenella frontalis) and pantropical spotted dolphin (Stenella attenuata), based on sightings, strandings, and preserved specimens (Cuervo et al., 1986; Prieto-Rodríguez, 1988; Vidal, 1990; Palacios, 1993; Flórez-González and Capella, 1995). Given the ecological importance of the region, the present study was conceived as a first attempt at characterizing cetacean occurrence around Santa Marta in a systematic manner. The study was conducted between August and November of 2004 and between January and August of 2005, using primarily boat-based surveys from platforms of opportunity and land-based surveys from fixed points. This information was supplemented with records from secondary sources when they were supported by photographic and/or filmic material, and with welldocumented observations made by previously trained personnel. For logistic purposes, the region was divided into five zones, beginning in the southwest at La Loma Point $\left(11^{\circ} 06^{\prime} 59^{\prime \prime} \mathrm{N}, 74^{\circ} 14^{\prime} 04^{\prime \prime} \mathrm{W}\right)$, and ending at Arrecifes $\left(11^{\circ} 20^{\prime} 22^{\prime \prime} \mathrm{N}, 73^{\circ} 58^{\prime} 19^{\prime \prime} \mathrm{W}\right)$, in the northeast. These zones are labeled in Figure 1 as: Airport $(A)$, Gaira Bay (B), Santa Marta Bay $(C)$, Granate $(D)$, and TNNP $(E)$.

Boat-based surveys were made parallel to the coastline, from a variety of boats equipped with outboard engines. During the surveys, two trained observers looked out for cetaceans with and without the aid of binoculars (Tasco ${ }^{\circledR}$ $10 \times 50 \mathrm{~mm}$ ), at speeds between 10 and $15 \mathrm{~km} / \mathrm{h}$, and a distance of 200 to $2000 \mathrm{~m}$ from the coast. Once cetaceans were sighted, they were approached to record their geographic position (GPS Garmin $® 12$ ), species identity, group structure, behavior, and other information such as the occurrence of natural marks. Land-based surveys were conducted at four fixed points within zones $A-D$, all of them from outposts at heights greater than $20 \mathrm{~m}$ above sea level, within $20 \mathrm{~m}$ from the coastline, and with an effective radial field-of-view of about 2000m (Figure 1). Finally, secondary observations were compiled, including photographs, films, and reliable accounts. Altogether, 155 boat-based trips were completed, distributed in the five zones $A-E$, for a total of $1012.5 \mathrm{~km}$ and $70 \mathrm{~h}$ of effort. In addition, 17 days of observation were conducted from the land-based points, of 10 hours each (0700h to $1700 \mathrm{~h}$ ), for a total of $174.5 \mathrm{~h}$ (Figure 1). The filmic and photographic information, as well as the verified testimonies, provided reliable data for five reliably records. A total of 28 cetacean records were obtained during the study (Table 1): 25 sightings, two incidental captures, and one beach-cast skeleton. These correspond to seven species: ordinary Bryde's whale, short-finned pilot whale (Globicephala macrorhynchus), marine tucuxi, pantropical spotted dolphin, striped dolphin (Stenella coeruleoalba), Atlantic spotted dolphin (the most recorded), and common bottlenose dolphin.

\footnotetext{
${ }^{1}$ Universidad Jorge Tadeo Lozano. Departamento de Biología Marina. Carrera 2a No. 11-68, El Rodadero, Santa Marta, Colombia.

${ }^{2}$ Current address: Instituto Politécnico Nacional - Centro Interdisciplinario de Ciencias Marinas, Departamento de Oceanología, Laboratorio de Ecología de Mamíferos Marinos. Av. IPN s/n Col. Playa Palo de Santa Rita 23096. La Paz, B.C.S. Mexico.

* Corresponding author, e-mail: mpardor0600@ipn.mx.

${ }^{3}$ Joint Institute for Marine and Atmospheric Research, University of Hawai, 1000 Pope Road, MSB 312, Honolulu, HI 96822 USA.

${ }^{4}$ NOAA, NMFS, Southwest Fisheries Science Center, Environmental Research Division. 1352 Lighthouse Avenue, Pacific Grove, CA 93950-2097 USA.

${ }^{5}$ Molina, A. (1990) Estudio geológico de la plataforma continental Caribe (Santa Marta-Punta Morro Hermoso). Page 120 In Memorias, VII Seminario Nacional de Ciencias y Tecnologías del Mar, 30 October - 2 November, Cali, Colombia.
} 


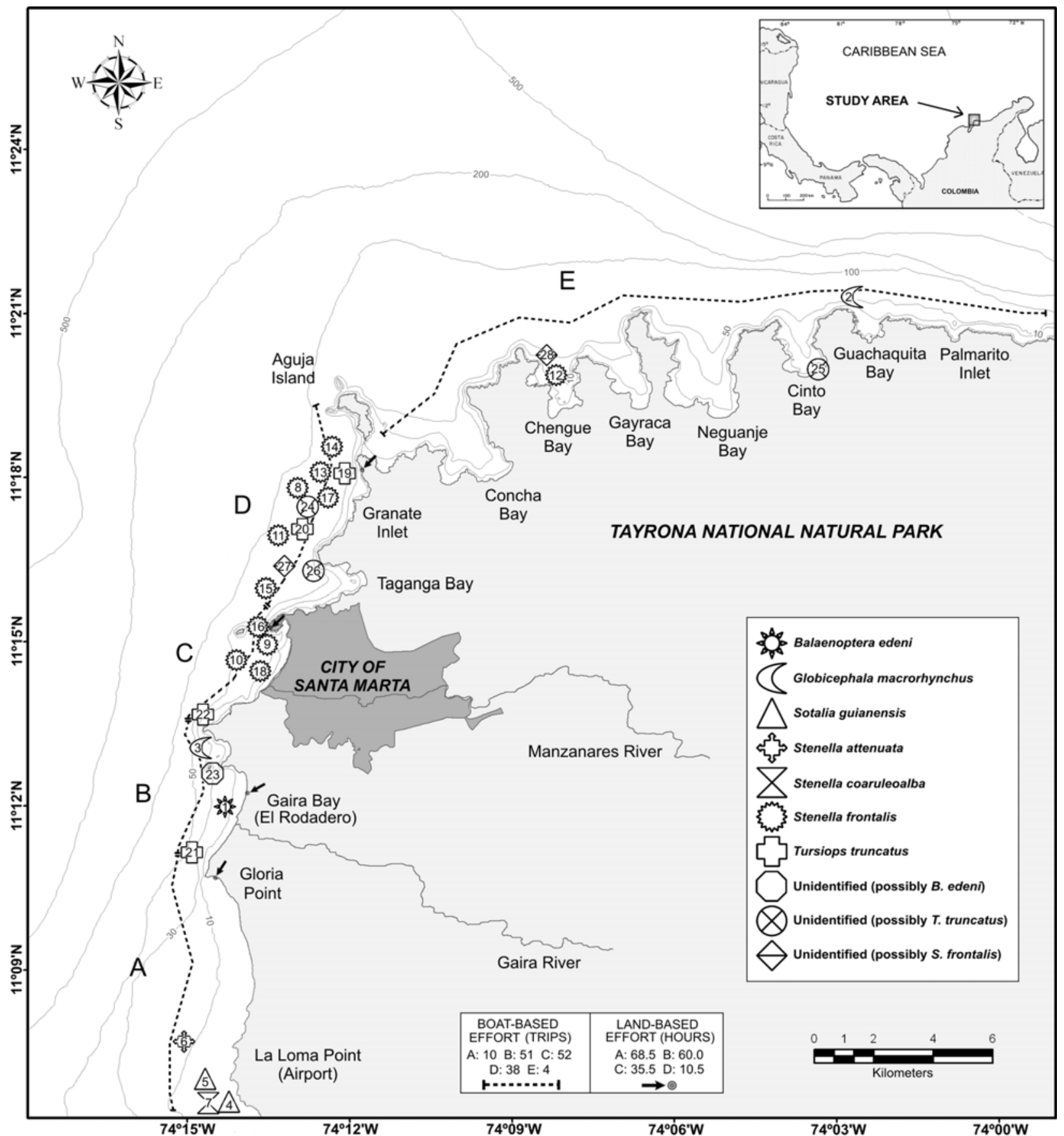

Figure 1. Map of the study area, showing the five zones $A-E$, the routes of boat-based surveys (dotted lines), and the location of the outposts (black arrows) used for the land-based surveys. Insets show the number of trips (for the boat-based surveys) and the effort hours (for the land-based surveys). The map also shows the location of all the records for the period August 2004 - August 2005. The numbers inside the record symbols correspond to those in Table 1. Source of base map: Sistema de Información Ambiental Marino (SIAM), LabSI, INVEMAR, 2006.

Ordinary Bryde's whale. The only record corresponds to a sighting, initially detected within Gaira Bay (Figure 1) from the land-based point. It was then picked up by the survey boat, and followed for about two hours. The animal moved in erratic, circling patterns, suggestive of feeding activities. Its dive intervals ranged from one to two minutes, although towards the end of the follow-up, its behavior shifted to traveling, with more prolonged dive times. This species has been previously reported for Gaira and Santa Marta Bays (Prieto-Rodríguez, 1988; Vidal, 1990), in association with the seasonal upwelling phenomenon occurring during the first months of the year (January and March). Sightings off Santa Marta Bay have consisted of small groups or solitary animals (FlórezGonzález and Capella, 1995). In contrast, in the Guajira region $\left(11^{\circ} 36^{\prime} \mathrm{N}, 72^{\circ} 58^{\prime} \mathrm{W}\right)$, where the upwelling is more 
permanent year-round, the species has been reported in May (Vidal, 1990), at a time when this phenomenon is not active in Santa Marta and the TNNP. The sighting in this study (February) corroborates the seasonal occurrence pattern of the species in association with upwelling centers. During this season, ordinary Bryde's whales may find in Santa Marta a reliable food source based on the abundant round sardinella (Sardinella aurita) and Atlantic thread herring (Opisthonema oglinum), both schooling fish whose populations appear to closely depend on the upwelling-driven productivity (Manjarrés et al., 1993).
Short-finned pilot whale. It was recorded on two occasions (Figure 1), in both cases traveling. These are the first recorded live sightings for the Colombian Caribbean, since the previous records (Vidal, 1990) are of a mass stranding on San Andrés Island $\left(12^{\circ} 32^{\prime} \mathrm{N}, 81^{\circ} 43^{\prime} \mathrm{W}\right)$, and several individual strandings along the coast of the Guajira region. Given the steep bathymetric profile of the study area, it is possible that this typically offshore species uses the near-shore habitats during the daytime for transiting or resting, after feeding at night in deeper habitats, as has been documented off

Table 1. Details of the records by species recorded in the Santa Marta region, Colombian Caribbean.

\begin{tabular}{|c|c|c|c|c|c|c|c|}
\hline$\#$ & SPECIES & ZONE & $\begin{array}{c}\text { DATE } \\
(\mathrm{D} / \mathrm{M} / \mathrm{Y}) \\
\end{array}$ & $\begin{array}{c}\text { TIME } \\
\text { (HOURS) } \\
\end{array}$ & $\begin{array}{c}\text { DISTANCE } \\
\text { TO SHORE }(\mathrm{m}) \\
\end{array}$ & $\begin{array}{c}\text { GROUP } \\
\text { STRUCTURE } \\
\end{array}$ & BEHAVIOR \\
\hline & \multicolumn{7}{|c|}{ Balaenoptera brydei } \\
\hline 01 & & Gaira Bay $(B)$ & $15 / 02 / 2005$ & 0730 & $1000-2500$ & $1(1 A)$ & Feeding / traveling \\
\hline \multicolumn{8}{|c|}{ Globicephala macrorhynchus } \\
\hline 02 & & Guachaquita $(E)$ & $04 / 01 / 2005$ & 1100 & $<500$ & $60(C, J, A)$ & Traveling \\
\hline 03 & & Gaira Bay $(B)$ & $-/ 01 / 2005$ & Morning & 2000 & $30(30 u)$ & Traveling \\
\hline \multicolumn{8}{|c|}{ Sotalia guianensis } \\
\hline 04 & & Airport $(A)$ & $-/ 09 / 2003$ & Morning & - & $2(1 C, 1 A)$ & Entanglement \\
\hline 05 & & Airport $(A)$ & $10 / 09 / 2004$ & Morning & 1000 & $10(10 U)$ & Traveling \\
\hline \multicolumn{8}{|c|}{ Stenella attenuata } \\
\hline 06 & & Airport $(A)$ & $17 / 10 / 2004$ & 0802 & 1000 & $3(1 C, 2 A)$ & Feeding \\
\hline \multicolumn{8}{|c|}{ Stenella coeruleoalba } \\
\hline 07 & & Airport $(A)$ & $12 / 06 / 2002$ & 2200 & - & $1(1 C)$ & Stranding \\
\hline \multicolumn{8}{|c|}{ Stenella frontalis } \\
\hline 08 & & Granate $(D)$ & $26 / 06 / 2004$ & Morning & - & $3(3 A)$ & Traveling \\
\hline 09 & & Santa Marta $(C)$ & $01 / 07 / 2004$ & Morning & $<500$ & $30(30 U)$ & Traveling \\
\hline 10 & & Santa Marta $(C)$ & $05 / 07 / 2004$ & Morning & $<500$ & $25(25 U)$ & Traveling \\
\hline 11 & & Granate $(D)$ & $10 / 08 / 2004$ & Morning & $<500$ & $3(3 A)$ & Traveling \\
\hline 12 & & Chengue $(E)$ & $01 / 09 / 2004$ & 1300 & $<500$ & $12(2 C, 10 A)$ & Traveling \\
\hline 13 & & Granate $(D)$ & $03 / 10 / 2004$ & 1330 & 500 & $10(10 U)$ & Traveling \\
\hline 14 & & Granate $(D)$ & $01 / 11 / 2004$ & 0915 & 500 & $5(2 C, 3 A)$ & Traveling \\
\hline 15 & & Taganga $(D)$ & $22 / 01 / 2005$ & Morning & 1000 & $1(1 A)$ & Traveling \\
\hline 16 & & Santa Marta $(C)$ & $25 / 03 / 2005$ & 0925 & 30 & $30(30 U)$ & Traveling \\
\hline 17 & & Granate $(D)$ & $08 / 04 / 2005$ & 0830 & 50 & $10(10 U)$ & Traveling \\
\hline 18 & & Santa Marta $(C)$ & $15 / 04 / 2005$ & 0910 & $>500$ & $10(10 U)$ & Traveling \\
\hline \multicolumn{8}{|c|}{ Tursiops truncatus } \\
\hline 19 & & Granate $(D)$ & $08 / 06 / 2004$ & Morning & - & $2(2 A)$ & Traveling \\
\hline 20 & & Granate $(D)$ & $28 / 01 / 2005$ & Morning & $>500$ & $2(2 A)$ & Traveling \\
\hline 21 & & Gaira Bay $(B)$ & $18 / 03 / 2005$ & 1000 & $500-1000$ & $15(3 C, 5 J, 7 A)$ & Feeding / traveling \\
\hline 22 & & Santa Marta $(C)$ & $18 / 08 / 2005$ & 0940 & $100-300$ & $20(3 C, 4 J, 13 A)$ & Traveling \\
\hline \multicolumn{8}{|c|}{ Unidentified whale (possibly B. brydei) } \\
\hline 23 & & Gaira Bay $(B)$ & $15 / 02 / 2005$ & 1730 & 1000 & $1(1 U)$ & - \\
\hline \multicolumn{8}{|c|}{ Unidentified dolphin (possibly T. truncatus) } \\
\hline 24 & & Granate $(D)$ & $11 / 11 / 2003$ & Morning & 100 & $2(1 C, 1 A)$ & Traveling \\
\hline 25 & & Cinto $(E)$ & $15 / 05 / 2004$ & Morning & - & $1(1 U)$ & - \\
\hline 26 & & Taganga $(D)$ & $21 / 05 / 2004$ & Morning & $>500$ & $1(1 A)$ & Traveling \\
\hline \multicolumn{8}{|c|}{ Unidentified dolphin (possibly S. frontalis) } \\
\hline 27 & & Taganga $(D)$ & $24 / 09 / 2004$ & Morning & $>800$ & $1(1 A)$ & Traveling \\
\hline 28 & & Chengue $(E)$ & $29 / 10 / 2004$ & Morning & 300 & $10(10 U)$ & Traveling \\
\hline
\end{tabular}

Abbreviations in group structure are: $C=$ calf, $J=$ juvenile, $A=$ adult; and $U=$ undetermined. 
Hawaii (Baird et al., 2003 ${ }^{6}$ ) and the Canary Islands (Heimilich-Boran, 1993).

Marine tucuxi. It was recorded on two occasions; a sighting and an incidental capture. A lactating mother and a juvenile became entangled in a discarded artisanal gillnet, and died later. A necropsy was conducted, but the cause of death was not evident. The juvenile presented deep wounds, mainly to the caudal peduncle, that already were healing over the net, so it is believed that the animal had been entangled for some time, unlike the mother, whose injuries were superficial. The sighting record corresponds to a traveling group of around 10 individuals, seen in zone $A$, about $1000 \mathrm{~m}$ from the coast (Figure 1). The species appears to be common in zone $A$, which lies at the northern end of the Gulf of Salamanca, and presents a transitional geomorphology influenced by the great coastal-estuarine mangrove system of "Ciénega Grande de Santa Marta". Sedimentation rates in this system are much higher than further to the north, resulting in a shallow, gently sloped bathymetric profile (Pujos et al., 1986). This agrees well with the species' affinity for near-shore, estuarine-influenced habitats (Borobia et al., 1991; Geise et al., 1999).

Pantropical spotted dolphin. In the single sighting of this species (Figure 1), feeding activity was evident. This is the first live report of the species in coastal waters of the Colombian Caribbean. Previously, it was sighted in oceanic waters $216 \mathrm{~km}$ off Aguja Island (Jefferson and Lynn, 1994). A stranding was also reported at the Rosario Islands $\left(10^{\circ} 09^{\prime} \mathrm{N}, 75^{\circ} 45^{\prime} \mathrm{W}\right)$, and a skull was found in Gayraca (TNNP) (Vidal, 1990). Since only a single record of the species was obtained during this study, it is not possible to make inferences about its local occurrence.

Striped dolphin. A net entanglement of a striped dolphin calf took place in zone $A$ on 12 June 2002. The individual was transferred alive to the pool of a local aquarium, and its initial condition was described as "unstable", with sudden and erratic movements in the pool, which stopped later. It had a wound on the jaw, which was partially separated from the head, and its feces contained numerous parasites, probably trematodes. The calf, of $128 \mathrm{~cm}$ in length and $37 \mathrm{~kg}$, died $46 \mathrm{~h}$ after being transferred to the aquarium. A necropsy was conducted, indicating only an infestation of parasites in the brain, but no confirmed cause of death. This is the first time that the striped dolphin is confirmed for the Colombian Caribbean. Although Cuervo et al. (1986) reported the species near the Rosario Islands, their record lacks any details that substantiate a positive identification, to the extent that Flórez-González and Capella (1995) disregarded all the records from those authors, considering them unreliable. The occurrence of $S$. coeruleoalba in the Santa Marta region is probably rare, considering the oceanic nature of the species and its overall infrequency in the Caribbean (Debrot et al., 1998; Mignucci-Giannoni, 1998).

Atlantic spotted dolphin. For the 11 sightings of the species (Figure 1), group size varied from 1-30, being more common those greater than $10(\bar{x}=12.6 \pm 10.7$ s.d.). The species tended to be found where the bathymetric gradient is more pronounced, but otherwise no clear distribution pattern was detected, and it was never seen feeding. Thus, it is believed that the groups sighted are oceanic in nature, and that they make brief incursions to the deeper coastal zones, using them occasionally for transit. Atlantic spotted dolphins have only been reported twice before: once in Gaira Bay (D.M. Palacios, personal observations, included in Flórez-González and Capella, 1995), and once about $39 \mathrm{~km}$ northeast of Arrecifes (TNNP) (Perrin et al., 1987).

Common bottlenose dolphin. The observed groups (Figure 1) were usually traveling, except for the sighting in Gaira Bay, in which the group alternated its travel with feeding on fish at the surface, made evident by the association with birds, mainly magnificent frigate birds (Fregata magnificens). Considering the distribution of the records, it can be assumed that the species is found throughout the study area, including zone $A$. It may use the coastal region of Santa Marta and the TNNP for foraging as well as for resting purposes within the bays. The species has only been sighted once previously in Gaira Bay (D.M. Palacios, personal observations, in Flórez-González and Capella, 1995), and captures for aquaria have been also documented for Santa Marta and Cartagena (Vidal, 1990).

Ecological considerations. The combination of a complex geomorphology, the presence of diverse coastal environments in a relatively small area, and the local high biological production make the Santa Marta and TNNP region a potentially exploitable habitat for a variety of species for purposes of foraging, resting, or transiting. Active feeding was observed for three species (ordinary Bryde's whale, pantropical spotted dolphin, and common bottlenose dolphin), suggesting that they take advantage of the seasonal influx of large schools of pelagic fish like round sardinella, Atlantic thread herring, frigate tuna (Auxis thazard), and little tunny (Euthynnus alletteratus), associated with the wind-driven upwelling and the fertilization by continental waters. For other species, the presence of protected bays near deep water may offer protection and a resting place from open-ocean currents and winds. Since the exploration of this study was limited to a narrow strip near the coast, it is not possible to advance conclusions about the true

\footnotetext{
${ }^{6}$ Baird, R. W., D. J. McSweeney, M. R. Heithaus and G.J. Marshall. (2003) Short-finned pilot whale diving behavior: deep feeders and day-time socialites. In Abstracts, 15th Biennial Conference on the Biology of Marine Mammals, 14 - 19 December, Greensboro, NC, USA.
} 
distribution or abundance of the different species throughout the region. It will be necessary to carry out systematic oceanic surveys to quantify the relative abundance and distribution patterns of the most abundant species.

Anthropogenic threats. It is important to evaluate in detail the impacts from anthropogenic pressure, especially the incidental mortality by entanglement in artisanal gillnets. Aside from the two cases documented in this study, it is informally known that this is a common occurrence in the adjacent Gulf of Salamanca, particularly involving marine tucuxis. Other detected sources of pressure include possible percussion injuries and acoustic pollution resulting from fishing with explosives, which is a common practice in the region and that has been previously implicated in a mass stranding of Atlantic spotted dolphins in zone A (Palacios, 1993). The industrial marine traffic in Santa Marta Bay, where an international shipping port is located, and the vicinity of the airport, with a coal- and oil-supply wharf are additional sources of noise pollution.

\section{Acknowledgements}

The authors wish to thank the following institutions for their logistical support: Universidad de Bogotá Jorge Tadeo Lozano, Instituto de Investigaciones Marinas y Costeras (INVEMAR), Fundación Red Colombiana de Varamientos (IASSOS), Fundación Omacha, Armada Nacional de Colombia (Dirección General Marítima, Capitanía de Puerto and Cuerpo de Guardacostas), Corporación Autónoma Regional del Magdalena (CORPAMAG), ECOPETROL, Acuario Mundo Marino, Tienda de Buceo El Rodadero, Escuela de Buceo Vida Marina, Centro de Buceo Caribbean Divers, and Club de Pesca Punta Aguja. The following people supported the fieldwork: Aminta Jáuregui, Andrés Franco, Marcela Grijalva, Nancy C. Jiménez, Carolina Domínguez, Anthony Combatt, Erwin González, Andrés Lozano, Sandra Pérez, and Diana Vargas. Advice during the study was provided by Aminta Jáuregui and José Manuel Ávila. Useful comments to an earlier version of the manuscript were provided by Fernando Trujillo and Koen Van Waerebeek.

\section{References}

Borobia, M., Siciliano, S., Lodi, L. and Hoek, W. (1991) Distribution of the South American dolphin Sotalia fluviatilis. Canadian Journal of Zoology 69: 1025-1039.

Bula-Meyer, G. (1985) Un núcleo nuevo de surgencia en el Caribe colombiano detectado en correlación con las macroalgas. Boletín Ecotrópica (12): 3-25.

Cuervo, A., Hernández-Camacho, J. and Cadena, A. (1986) Lista actualizada de los mamíferos de Colombia. Anotaciones sobre su distribución. Caldasia 15(71-75): 471-501.
Debrot, A.O., DeMeyer, J.A. ANd Deventer, P.J.E. (1998) Additional records and a review of the cetacean fauna of the leeward Dutch Antilles. Caribbean Journal of Science 34(3-4): 204-210.

Díaz, J.M., Barrios, L.M., Cendales, M.H., Garzón-Ferreira, J., Geister, J., López-Victoria, M., Ospina, G., Parra-Velandia, F., Pinzón, J., Vargas-Angel, B., Zapata, F. And Zea, S. (2000) Áreas coralinas de Colombia. INVEMAR, Serie Publicaciones Especiales No 5, Santa Marta, Colombia.

Flórez-GonZÁLEZ, L. AND CAPElla, J. (1995) Mamíferos acuáticos de Colombia. Una revisión y nuevas observaciones sobre su presencia, estado del conocimiento y conservación. Informe del Museo del Mar, Universidad Jorge Tadeo Lozano (39): 1-29.

Franco-Herrera, A., CAstro, L. AND Tigreros, P. (2006) Plankton dynamics in the South Central Caribbean Sea: strong seasonal changes in a coastal tropical system. Caribbean Journal of Science 42(1): 24-38.

GARZÓn-Ferreira, J. and CANO, M. (1991) Tipos, distribución, extensión y estado de conservación de los ecosistemas marinos costeros del Parque Nacional Natural Tayrona. Informes del Instituto de Investigaciones Marinas y Costeras - INVEMAR, Santa Marta, Colombia.

Geise, L., Gomes, N. AND CerqueirA, R. (1999) Behavior, habitat use and population size of Sotalia fluviatilis (Gervais, 1853) (Cetacea, Delphinidae) in the Cananéia estuary region, São Paulo, Brazil. Revista Brasileira de Biologia 59(2): 183-194.

HeImlich-Boran, J.R. (1993) Social organization of the short-finned pilot whale, Globicephala macrorhynchus, with special reference to the social ecology of delphinids. Ph.D. thesis, Cambridge University, Cambridge, United Kingdom.

JEFFERSON, T.A. AND LYNN, S.K. (1994) Marine mammal sightings in the Caribbean Sea and Gulf of Mexico, summer 1991. Caribbean Journal of Science 30(1-2): 83-89.

Manjarrés, L., Infante, J., Rueda, A. and Escorcia, F. (1993) Carta pesquera del área de Santa Marta. Pages 45-53 in Proyecto integral de investigaciones y desarrollo de la pesca Artesanal y Marítima en el área de Santa Marta. INPA - Universidad del Magdalena, Santa Marta, Colombia.

Mignucci-Giannoni, A.A. (1998) Zoogeography of cetaceans off Puerto Rico and the Virgin Islands. Caribbean Journal of Science 34(3-4): 173-190.

MÜLLER, K. (1979) Interrelación entre salinidades y temperatura en la bahía de Santa Marta. Anales del Instituto de Investigaciones Marinas y Costeras de Punta de Betín (11): 219-226.

Palacios, D.M. (1993) Más sobre varamientos causados por explosiones submarinas. El Observador Informativo - Fundación Ecuatoriana para el Estudio de Mamíferos Marinos 5(1): 2.

Perrin, W.F., Mitchell, E.D., Mead, J.G., Caldwell, D.K., Caldwell, M.C., van Bree, P.J.H. and Dawbin, W.H. (1987) Revision of the spotted dolphins, Stenella spp. Marine Mammal Science 3(2): 99-170.

Prieto-Rodríguez, M. (1988) Reporte de algunos cetáceos del Caribe colombiano. Boletín de la Facultad de Biología Marina (Universidad Jorge Tadeo Lozano, Bogotá) 8: 30-40.

Pujos, M., Pagliardini, L., Steer, R., Vernette, G. and Weber, O. (1986) Influencia de la contracorriente norte colombiana para la circulación de las aguas en la plataforma continental: Su acción sobre la dispersión de los efluentes en suspensión del río Magdalena. Boletín Científico CIOH (6): 3-15. 
Ramírez, G. (1983) Características fisicoquímicas de la bahía de Santa Marta (agosto 1980 - julio 1981). Anales del Instituto de Investigaciones Marinas y Costeras (13): 111-121.
Vidal, O. (1990) Lista de los mamíferos acuáticos de Colombia. Informe del Museo del Mar, Universidad Jorge Tadeo Lozano (37): 1-18.

Received 5 June 2006. Accepted 21 November 2006. 